\title{
ANALISIS PENURUNAN KUALITAS MUTU KAYU PADA BANGUNAN CAGAR BUDAYA DENGAN METODE NON DESTRUCTIVE TEST (Studi Kasus Bangunan Cagar Budaya Masjid Gedhe Mataram Daerah Istimewa Yogyakarta)
}

\author{
Darmono, Maris Setyo Nugroho, Slamet Widodo, Faqih Ma'arif \\ Jurusan Pendidikan Teknik Sipil dan Perencanaan, Fakultas Teknik, Universitas Negeri Yogyakarta \\ Email: darmono@uny.ac.id
}

\begin{abstract}
ABSTRAK
Penelitian bertujuan untuk mengetahui mechanical properties material kayu Bangunan Cagar Budaya dengan nondestructive test. Penelitian ini menggunakan metode pengujian lansung dilapang menggunakan Ultrasonic Pulse Velocity (UPV). Terdapat dua variable yang digunakan yaitu kolom cacat dan kolom utuh untuk mengetahui perbedaan nilai cepat rambat gelombang. Jumlah sampel yang digunakan sebanyak enam buah dengan pengambilan data masing-masing sampel sebanyak lima kali. Hasil pengujian menunjukkan bahwa nilai kadar air dan berat jenis kayu sebesar $15,03 \%$ dan 0,62 . Sedangkan hasil pengujian UPV pada kolom cacat dan utuh diperoleh cepat rambat gelombang sebesar $0,71 \mathrm{~km} / \mathrm{s}$ dan $1,21 \mathrm{~km} / \mathrm{s}$. Berdasarkan hasil analisis menunjukkan bahwa nilai $\mathrm{MOE}_{d}$ pada kolom utuh sebesar 9.374,37 MPa, sedangkan $\mathrm{MOE}_{d}$ pada kolom cacat sebesar 3.240,62 MPa.
\end{abstract}

Kata kunci: mechanical properties kayu, bangunan cagar budaya, ultrasonic pulse velocity

\begin{abstract}
This study aims to determine the mechanical properties of the wood material for the Cultural Heritage Building with a non-destructive test. This study used a direct field testing method using Ultrasonic Pulse Velocity (UPV). There are two variables used, namely the defective column and the solid column to determine the difference in the value of the fast propagation of the waves. The number of samples used was six with data collection for each sample five times. The test results showed that the moisture content and density of wood were $15.03 \%$ and 0.62 . While the UPV test results on defective and solid columns obtained wave propagation velocity of $0.71 \mathrm{~km} / \mathrm{s}$ and $1.21 \mathrm{~km} / \mathrm{s}$. Based on the analysis result, it shows that the MOEd value in the whole column is 9,374.37 MPa, while the MOEd in the defective column is 3,240.62 MPa.
\end{abstract}

Keywords: mechanical properties of wood, cultural heritage buildings, ultrasonic pulse velocity 


\section{PENDAHULUAN}

Kayu merupakan material alam yang masih banyak diminati di beberapa daerah di Indonesia. Material utama pada bangunan tradisional terutama pada Bangunan Cagar Budaya Indonesia mayoritas menggunakan kayu. Peminat kayu sebagai material konstruksi meningkat dalam beberapa dekade terakhir, selain dari aspek struktur dari aspek arsitektur kayu dinilai indah, mewah, penuh seni, dan nyaman sebagai tempat tinggal. Namun sebagai material alam kayu tentu memiliki kekurangan yaitu kerusakan yang disebabkan oleh beberapa penyebab, diantaranya adalah cendawan/jamur, bakteri, serangga pengerek (rayap), dan pengausan mekanis. Agar dapat melestarikan Bangunan Cagar Budaya yang menggunakan material kayu diperlukan asesmen dan pemeliharaan, maka dari itu diperlukan analisis untuk mengetahui karakteriktik dari material kayu yang digunakan pada bangunan cagar budaya.

Menurut undang-undang No. 11 tahun 2010 tentang Cagar Budaya, pada pasal 5 disebutkan bahwa Cagar Budaya merupakan benda, bangunan, atau struktur yang berusia 50 tahun atau lebih, mewakili masa gaya paling singkat berusia 50 tahun, dianggap memiliki arti khusus bagi sejarah, ilmu pengetahuan, pendidikan, agama, dan memiliki nilai budaya bagi penguatan kepribadian bangsa. Salah satu Bangunan Cagar Budaya yang memiliki arti penting dalam sejarah perkembangan di Indonesia tepatnya di Provinsi Daerah Istimewa Yogyakarta pada Masjid Gedhe Mataram.

Sebagai upaya pelestarian cagar budaya dalam pengujian material harus diminimalisir adanya kerusakan pada material ataupun struktur bangunan cagar budaya. Sehingga diperlukan pengujian tanpa merusak (Non Destructive Test). Tujuan dari penelitian ini yaitu untuk mengetahui mechanical properties dengan pendekatan nilai modulus elastisitas dinamik serta mempertimbangkan aspek non-destructive test. Guna mendapatkan nilai karakteristik material kayu terhadap struktur bangunan yang diuji sehingga dapat diketahui kualitas material kayu yang ada pada bangunan Bangunan Cagar Budaya terutama pada bangunan yang ditinjau Masjid Gedhe Mataram Daerah Istimewa Yogyakarta

\section{Karakteristik Material Kayu}

Kayu sebagai bahan bangunan mempunyai kekuatan tertentu, terutama mengenai sifat fisik/mekanik. Dengan diketahui kekuatan untuk jenis kayu tertentu, maka konsumen akan memilih jenis kayu yang tepat sesuai penggunaan. Faktor-faktor yang mempengaruhi kekuatan kayu diantaranya adalah faktor biologis (mikroorganisme yang menyerang kayu), kadar air, dan berat jenis (Damanik, 2005).

Penelitian mechanical properties (analisis karakteristik material kayu) merupakan salah satu pengujian guna menentukan mutu kayu, mengukur dimensi kayu untuk mendapatkan volume, pengujian kadar air dan berat jenis, serta menentukan nilai kekuatan lenutr, tekan, dan tarik terhadap pengujian struktur kayu.

\section{Non Destructive Testing (NDT)}

Non-Destructive Test (NDT) adalah aktivitas tes atau inspeksi terhadap suatu benda untuk mengetahui adanya cacat, retak, atau discontinuity lain tanpa merusak benda yang kita tes atau inspeksi. Pada dasarnya, tes ini dilakukan untuk menjamin bahwa material yang kita gunakan masih aman dan belum melewati damage tolerance. Material pesawat diusahakan semaksimal mungkin tidak mengalami kegagalan (failure) selama 
masa penggunaannya (Hoyle, R.J., dan Pellerin, R.F, 1978).

\section{METODE}

Metode yang digunakan pada penelitian ini adalah metode eksperimen di lapangan (Masjid Gedhe Mataram). Standar pengujian mengacu pada ASTM D 4432-92 untuk kadar air, dan ASTM D 2395-14 untuk berat jenis, sedangkang pengujian nondestructive test metode Ultrasonc Pulse Velocity (UPV) mengacu pada ASTM C 597-2012. Penggunaan pengujian UPV menggunakan skema pengujian direct. Bagan alur penelitian dapat dilihat pada Gambar 1.

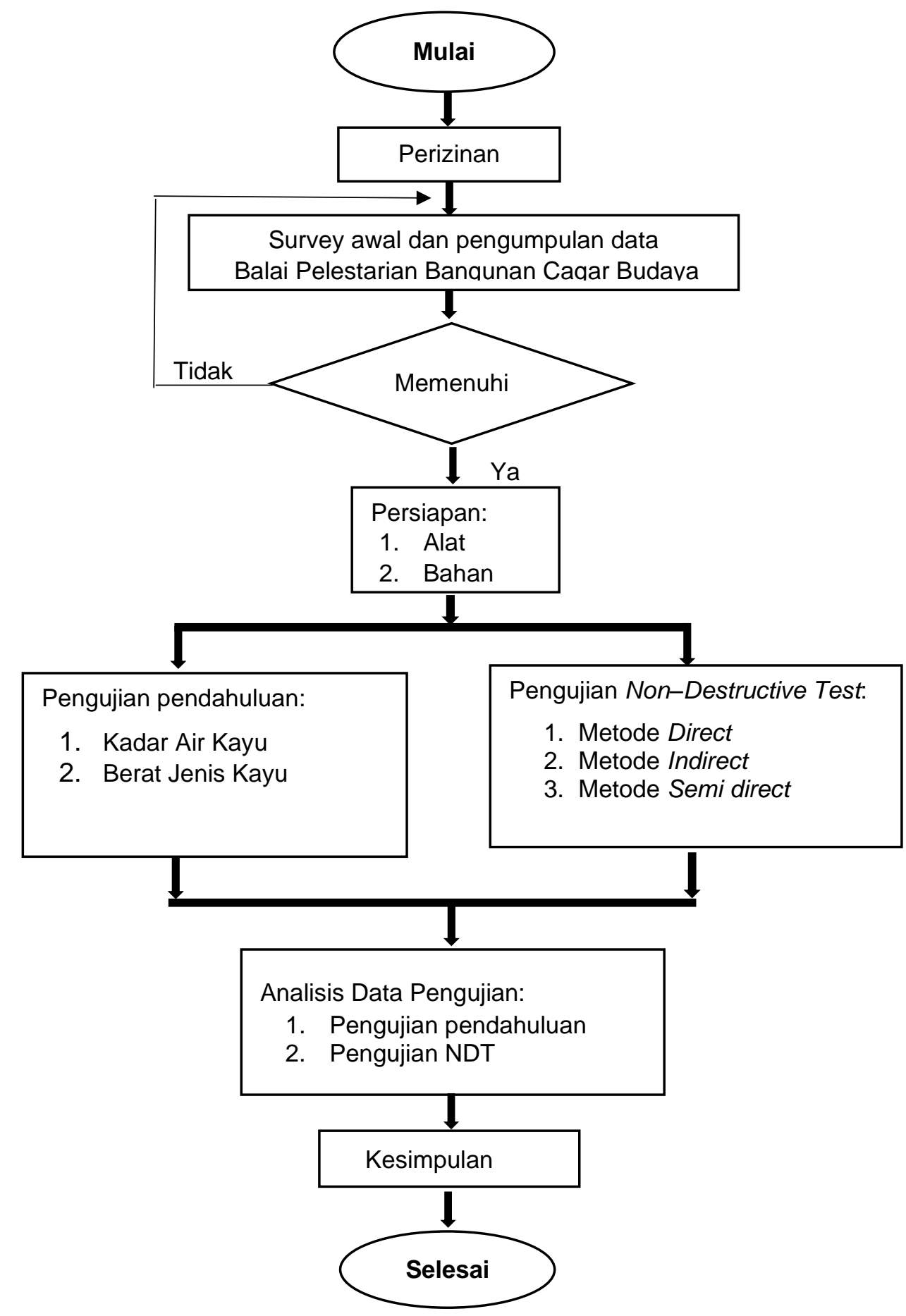

Gambar 1. Diagram Alir Penelitian 


\section{Pengujian Kadar Air}

Berdasarkan ASTM 4442-92 (Standard Test Methods for derection Moisture Content Measurement of Wood-Base materials), untuk menghitung kadar air kayu menggunakan rumus persamaan (1):

$\mathrm{MC} \%=\frac{\mathrm{A}-\mathrm{B}}{\mathrm{B}}$

Keterangan:

$\mathrm{MC}($ Measure Content $)=$

Kadar lengas kayu dalam persen (\%)

A = Massa orisinil, (gr)

$\mathrm{B}=$ Massa kering oven, (gr)

\section{Pengujian Berat Jenis}

Sedangkan untuk menghitung nilai berat jenis kayu berdasarkan ASTM D 2395-14 Standard Test Methods for Density and Specific Gravity (Relative Density) of Wood and Wood-Based Materials. Dapat dihitung dengan persamaan (2) sebagai berikut:

$\rho_{O}=\frac{m_{O}}{V_{O}}$

Keterangan:

$\rho_{O}=$ Berat jenis

$m_{o}=$ Spesimen kering oven seperti yang ditentukan (gr)

$\mathrm{V}=$ Volume spesimen kering oven $\left(\mathrm{cm}^{3}\right)$

\section{Non Destructive Test (NDT)}

Proses NDT menggunakan alat Ultrasonic Pulse Velocity (UPV) untuk mengukur kecepatan hantaran dari gelombang (pulse velocity) ultrasonik yang melewati suatu material. Standar atau prosedur dalam menggunakan metode pengujian ini dapat dilihat pada ASTM C 597. Nilai cepat rambat gelombang dapat dihirung menggunakan persamaan 3 berikut:

$V=\frac{L}{\Delta t}$
Dimana $\mathrm{V}$ adalah kecepatan perambatan gelombang ultrasonic $(\mathrm{km} / \mathrm{s}), \mathrm{L}$ adalah konstanta panjang lintasan gelombang $(\mathrm{m})$, dan $\Delta \mathrm{t}$ adalah travel time (s). Modulus dinamis diperoleh berdasarkan persamaan (4).

$\mathrm{MOE}_{\mathrm{dl}}=\frac{\mathrm{V}^{2} \times \rho}{\mathrm{g}}$

Dimana $\mathrm{MOE}_{\mathrm{dl}}$ adalah modulus elastisitas dinamis pada arah longitudinal $\left(\mathrm{kg} / \mathrm{cm}^{2}\right), \mathrm{V}$ adalah kecepatan perambatan gelombang $(\mathrm{m} / \mathrm{s}), \rho$ adalah kerapatan $\left(\mathrm{kg} / \mathrm{m}^{3}\right)$, $\mathrm{g}$ adalah konstanta gravitasi $\left(9,81 \mathrm{~m} / \mathrm{s}^{2}\right)$, dan $\mathrm{d}$ adalah selisih jarak antar transduser $(\mathrm{cm})$.

\section{HASIL DAN PEMBAHASAN}

\section{Kadar Air Kayu}

Sebelum dilakukan pengujian UPV, terlebih dahulu dilakukan pemerikasaan sifat fisik kayu yang meliputi pengujian kadar air dan berat jenis. Hasil pengujian kadar air disajikan pada Tabel 1 sebagai berikut:

Tabel 1. Kadar Air Kayu Jati Masjid Gedhe Mataram

\begin{tabular}{cc}
\hline $\begin{array}{c}\text { Kode Benda } \\
\text { Uji }\end{array}$ & $\begin{array}{c}\text { Kadar Air } \\
(\%)\end{array}$ \\
\hline SKM 1 & 15,79 \\
SKM 2 & 14,29 \\
SKM 3 & 15,00 \\
Rerata & 15,03 \\
\hline
\end{tabular}

Kadar air adalah banyaknya air yang ada di dalam kayu, yang umumnya dinyatakan sebagai persen terhadap berat kering oven kayu. Hasil pengujian menunjukan bahwa nilai rerata kadar kayu sebesar 15,03 \% (Gambar 2). Jika dibandingankan dengan hasil pengujian kadar air kayu jati yang telah dilakukan oleh Nugroho dkk, (2017) pada kayu jati hutan rakyat dengan nilai kadar air sebesar $14,6 \%$, tidak terdapat perbedaan niali kadar air yang signifikan. Adanya perbedaan nilai kadar air dapar diakibatkan dari kondisi kelembaban yang ada disekitar lingkungan. 
Analisis Penurunan Kualitas... (Darmono/ hal 191-199)

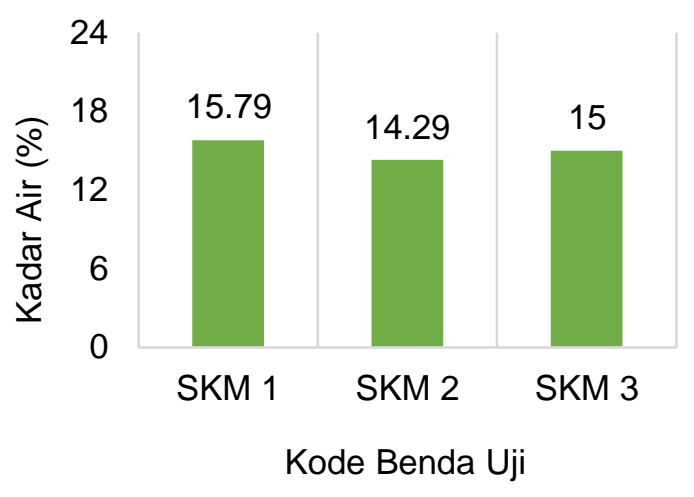

Gambar 2. Grafik Kadar Air

Keterangan:

SKM 1 = Sampel Kayu Masjid 1

SKM 2 = Sampel Kayu Masjid 2

SKM 3 = Sampel Kayu Masjid 3

SNI 03-3958 (1995) mensyaratkan bahwa batas maksimum kadar air adalah $20 \%$. Hasil pengujian sampel (Gambar 2) menunjukkan bahwa kadar air pada kayu bangunan Masjid Gedhe Mataram masih dibawah dari standar nilai kadar air yang disyaratkan oleh SNI.

\section{Berat Jenis}

Hasil pengujian berat jenis menunjukkan bahwa berat jenis kayu jati yang digunakan di Masjid Gedhe Mataram memiliki nilai berat jenis rerata 0.62 seperti yang telah disajikan pada Tabel 2. Jika dibandingkan dengan hasil penelitian nilai berat jenis kayu jati yang dilakukan oleh Nugroho dkk, (2017) pada kayu jati hutan rakyat memiliki nilai berat jenis kayu yang lebih tinggi yaitu 0.72 . Hal ini dapat disebabkan karena umur penggunaan kayu jati pada Masjid Gedhe Mataram yang sudah ratusan tahun, sehingga diidikasikan telah mengalami pelapukan mengingat sampel yang diambil merupakan kayu jati hasil pembongkaran proses renovasi Masjid Gedhe Mataram. Salah satu faktor yang mempengaruhi nilai berat jenis yaitu kepadatan suatu material jika material sudah mengalami pelapukan akan berdampak pada turunnya kepadatan material tersebut dan juga berat jenis material.
Tabel 2. Berat Jenis Jati Masjid Gedhe Mataram

\begin{tabular}{cc}
\hline $\begin{array}{c}\text { Kode Benda } \\
\text { Uji }\end{array}$ & Berat Jenis \\
\hline A & 0.60 \\
B & 0.65 \\
C & 0.62 \\
Rerata & 0.62 \\
\hline
\end{tabular}

Menurut PKKI NI 5:1961 tentang kelas kuat kayu ditinjau dari berat jenis, Kayu Jati Bangunan Cagar Budaya masuk kelas kuat II dengan nilai berat jenis 0,62 (Gambar 3). Kayu dengang kelas kuat II cocok digunakan untuk konstruksi berat yang terlindung berada di bawah atap dan tidak berhubungan dengan tanah basah. tahan rayap dan tahan air.

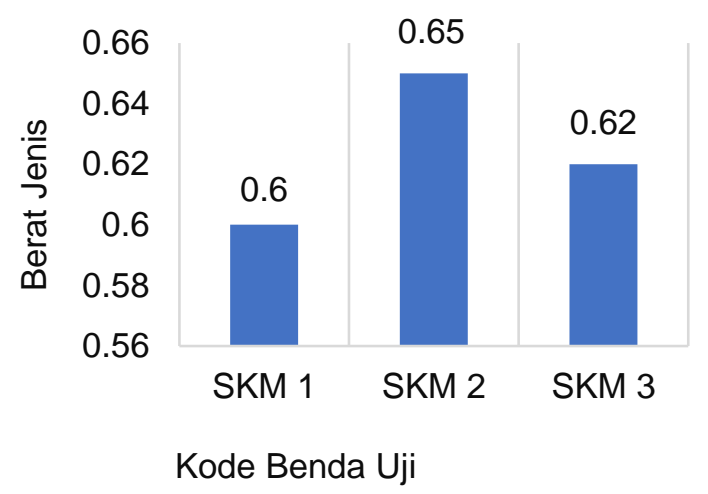

Gambar 3. Grafik Perbandingan Berat Jenis Benda Uji Kayu Jati Masjid Gedhe Mataram

Kelas kuat Kayu Jati Bangunan Cagar Budaya yang masuk pada kelas kekuatan II merupakan struktur kayu Jati dari hasil pemugaran Masjid Gedhe Mataram pasca musibah gempa bumi di Daerah Istimewa Yogyakarta tahun 2006. Kayu tersebut disimpan hingga sampai saat ini, sehingga Kayu Jati Bangunan Cagar Budaya mengalami penurunan kelas kekuatan kayu yang difaktorkan oleh cuaca, dan lingkungan.

Atlas Kayu Jilid I menyebutkan bahwa kayu Jati mempunyai nilai berat jenis diantara $0,62-0,75$, hasil pengujian mendapatkan nilai berat jenis rata-rata kayu jati sebesar 
0,62 sehingga menjadi pertimbangan dan acuan pada nilai berat jenis. Dapat disajikan bahwa nilai berat jenis masuk kedalam ketentuan Atlas Kayu Jilid I, sesuai dengan teori yang didaptakan oleh Brown et all., (1952) bahwa nilai berat jenis bervariasi diantara berbagai jenis pohon dan diantara pohon dari satu jenis yang sama dan juga sampel benda uji di ambil secara acak.

\section{Pengujian Ultasonic Pulse Velocity (UPV)}

Pengujian non-destructive test pada kolom yang diuji dengan metode UPV test merupakan tahap akhir dalam penelitian ini. Dari pengujian yang telah dilakukan maka akan diperoleh nilai cepat rambat gelombang (V), dan MOEd pada metode Direct Hasil pengujian tersebut menunjukkan sifat karakteristik struktur kayu yang telah diuji. Sebelum dilakukan pengujian, langkah pertama yaitu melakukan pendataan dan pengukuran pada tiga kolom utuh dan tiga kolom cacat. Posisi kolom yang diuji disajikan pada Gambar 4.
Pengujian Ultrasonic Pulse Velocity (UPV) dilaksanakan untuk mengetahui kecepatan perambatan ultrasonik pada kolom cacat dan kolom utuh. Hasil pengujian UPV pada kolom cacat disajikan pada Tabel 3 .

Tabel 3. Hasil Pengujian UPV Metode Direct Kolom Cacat

\begin{tabular}{|c|c|c|c|c|c|}
\hline $\begin{array}{l}\text { Kode } \\
\text { Kolom }\end{array}$ & Titik & $\begin{array}{l}\text { Jarak } \\
\text { Trans - } \\
\text { ducer } \\
(\mathrm{mm})\end{array}$ & $\begin{array}{c}\text { Travel } \\
\text { Time } \\
(\Delta \mathrm{T})\end{array}$ & $\begin{array}{c}V \\
(\mathrm{~km} / \mathrm{s})\end{array}$ & $\begin{array}{c}\text { Rerata } \\
\text { V } \\
(\mathbf{k m} / \mathbf{s})\end{array}$ \\
\hline \multirow{5}{*}{$\begin{array}{c}\text { KDC } \\
11\end{array}$} & 1 & 100 & 131 & 0,76 & \multirow{5}{*}{0,74} \\
\hline & 2 & 100 & 129 & 0,78 & \\
\hline & 3 & 100 & 134 & 0,75 & \\
\hline & 4 & 100 & 140,5 & 0,71 & \\
\hline & 5 & 100 & 138,5 & 0,72 & \\
\hline \multirow{5}{*}{$\begin{array}{c}\text { KDC } \\
12\end{array}$} & 1 & 100 & 133 & 0,75 & \multirow{5}{*}{0,79} \\
\hline & 2 & 100 & 132,5 & 0,75 & \\
\hline & 3 & 100 & 123 & 0,81 & \\
\hline & 4 & 100 & 121,5 & 0,82 & \\
\hline & 5 & 100 & 121,5 & 0,82 & \\
\hline \multirow{5}{*}{$\begin{array}{l}\text { KDC } \\
27\end{array}$} & 1 & 100 & 174 & 0,57 & \multirow{5}{*}{0,59} \\
\hline & 2 & 100 & 171,5 & 0,58 & \\
\hline & 3 & 100 & 173 & 0,58 & \\
\hline & 4 & 100 & 170 & 0,59 & \\
\hline & 5 & 100 & 154 & 0,65 & \\
\hline
\end{tabular}

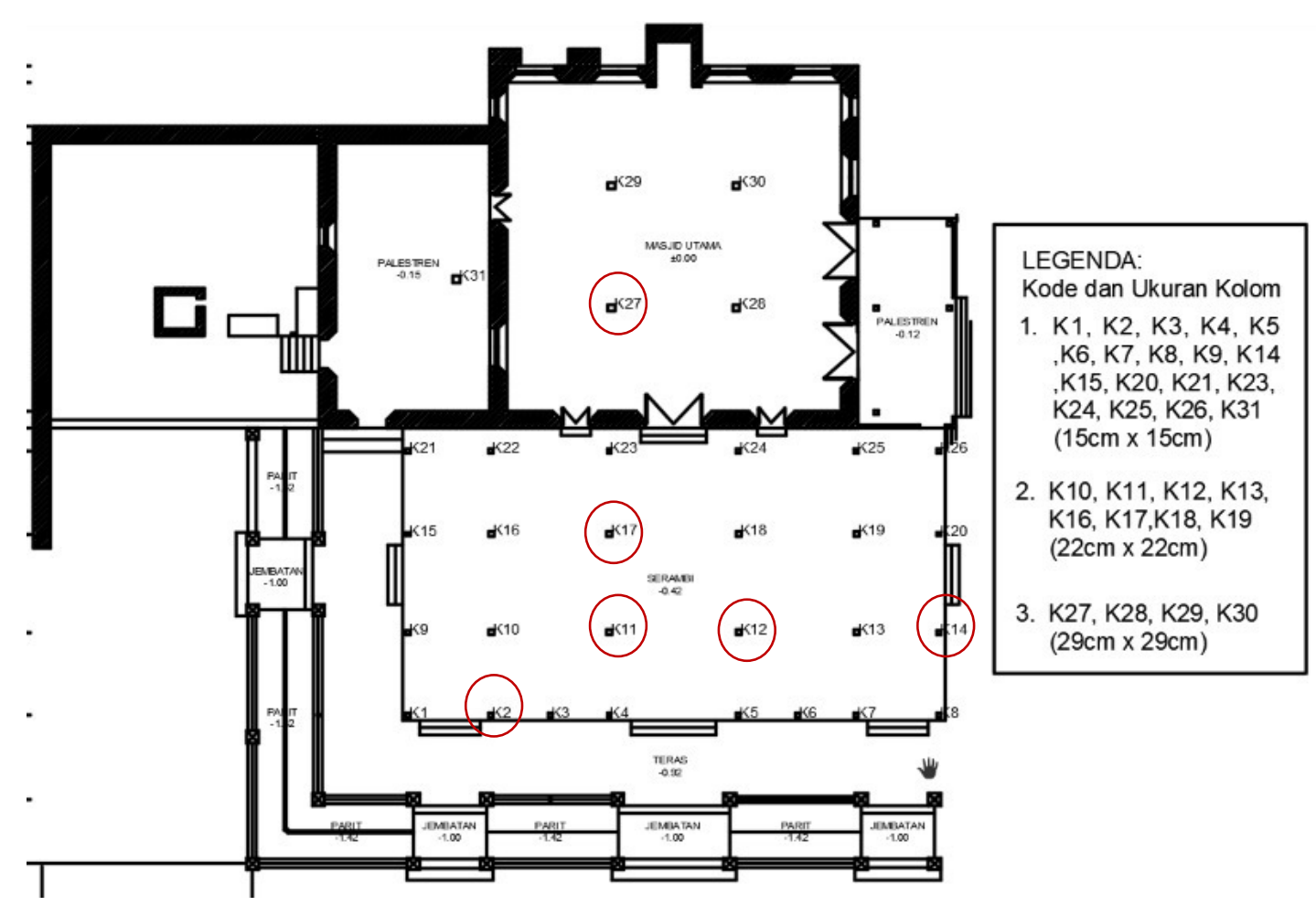

Gambar 4. Denah Masjid Gedhe Mataram dan Posisi Kolom yang Diuji 


\section{Analisis Penurunan Kualitas... (Darmono/ hal 191-199)}

Berdasarkan hasil analisis (Gambar 5) diketahui bahwa nilai Ultrasonic Pulse Velocity (UPV) dengan metode direct didapat hasil pengujian KDC 11, KDC 12, KDC 27 secara berturut-turut sebesar 0,74 $\mathrm{km} / \mathrm{s}, 0,79 \mathrm{~km} / \mathrm{s}, 0,59 \mathrm{~km} / \mathrm{s}$. Kecepatan tertinggi pada KDC 12 yaitu $0,79 \mathrm{~km} / \mathrm{s}$. Berdasarkan grafik tersebut menunjukkan bahwa kecepatan pada kolom cacat, KDC 11, KDC 12, dan KDC 27 dengan metode direct mempunyai hasil yang selalu stabil. Hanya saja hasil tersebut sangat kecil dikarenakan terdapat kecacatan pada kolom. Besarnya selisih antara KDC 12 dengan KDC 11 dan KDC 27 adalah 6,3\% dan $25,32 \%$.

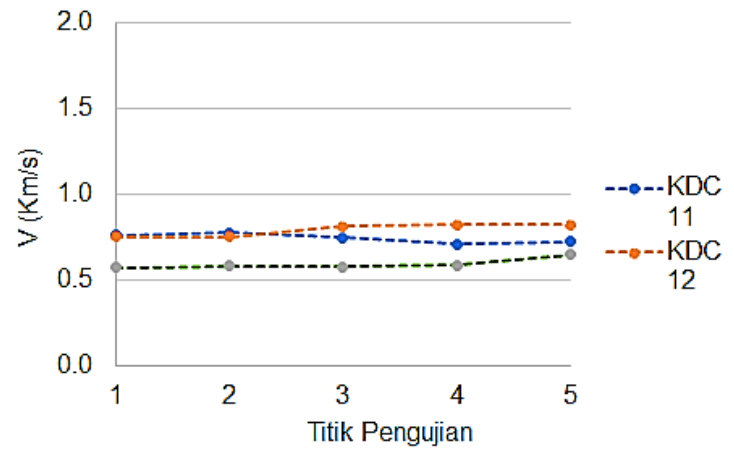

Gambar 5. Cepat Rambat Gelombang pada Kolom Cacat

Keterangan:

KDC $11=$ Kolom Direct Cacat 11

KDC $12=$ Kolom Direct Cacat 12

KDC 27 = Kolom Direct Cacat 27

Sedangkan hasil pengujian Ultrasonic Pulse Velocity (UPV) dengan metode direct pada kolom utuh didapat hasil pengujian KDU 2, KDU 14, KDU 17 secara berturut-turut sebesar 1,35 km/s, 1,30 km/s, 0,97 km/s. Kecepatan tertinggi pada KDU 2 yaitu 1,35 $\mathrm{km} / \mathrm{s}$ seperti yang disajikan pada Tabel 4 . Jika dibangingkan dengan nilai cepat rambat gelombang pada kolom cacat, cepat rambat gelombang pada kolom untuk lebih tinggi. Hal ini menunjukkan bahwa homogenitas material pada kolom utuh lebih bagus. Adanya cacat atau rongga pada kayu akan mempengaruhi cepat rambat gelombang pada kayu tersebut.
Tabel 4. Hasil Pengujian UPV Metode Direct Kolom Cacat

\begin{tabular}{|c|c|c|c|c|c|}
\hline $\begin{array}{l}\text { Kode } \\
\text { Kolom }\end{array}$ & Titik & $\begin{array}{l}\text { Jarak } \\
\text { Trans - } \\
\text { ducer } \\
(\mathrm{mm})\end{array}$ & $\begin{array}{l}\text { Travel } \\
\text { Time } \\
(\Delta \mathrm{T})\end{array}$ & $\begin{array}{c}V \\
(k m / s)\end{array}$ & $\begin{array}{c}\text { Rerata } \\
\text { V } \\
(\mathrm{km} / \mathrm{s})\end{array}$ \\
\hline \multirow{5}{*}{ KDU 2} & 1 & 100 & 74,5 & 1,34 & \multirow{5}{*}{1,35} \\
\hline & 2 & 100 & 74 & 1,35 & \\
\hline & 3 & 100 & 75 & 1,33 & \\
\hline & 4 & 100 & 72 & 1,39 & \\
\hline & 5 & 100 & 74 & 1,35 & \\
\hline \multirow{5}{*}{$\begin{array}{c}\text { KDU } \\
14\end{array}$} & 1 & 100 & 79 & 1,27 & \multirow{5}{*}{1,30} \\
\hline & 2 & 100 & 78,5 & 1,27 & \\
\hline & 3 & 100 & 79 & 1,27 & \\
\hline & 4 & 100 & 78 & 1,28 & \\
\hline & 5 & 100 & 71,5 & 1,40 & \\
\hline \multirow{5}{*}{$\begin{array}{c}\text { KDU } \\
17\end{array}$} & 1 & 100 & 106 & 0,94 & \multirow{5}{*}{0,97} \\
\hline & 2 & 100 & 102 & 0,98 & \\
\hline & 3 & 100 & 102,5 & 0,98 & \\
\hline & 4 & 100 & 104 & 0,96 & \\
\hline & 5 & 100 & 103,5 & 0,97 & \\
\hline
\end{tabular}

Gambar 6 menunjukkan bahwa kecepatan pada kolom utuh KDU 2, KDU 14, dan KDU 17 dengan metode direct mempunyai hasil yang selalu stabil. Besarnya selisih antara KDU 2 dengan KDU 14 dan KDU 17 adalah $3,7 \%$ dan $28,15 \%$. Adanya selisih nilai cepat rambat gelombang pada kolom utuh menunjukkan bahwa material kayu memiliki sifat unisotropik. Dengan sifat tersebut sangat memungkinkan homogenitas dan kekuatan material kayu tidak segaram.

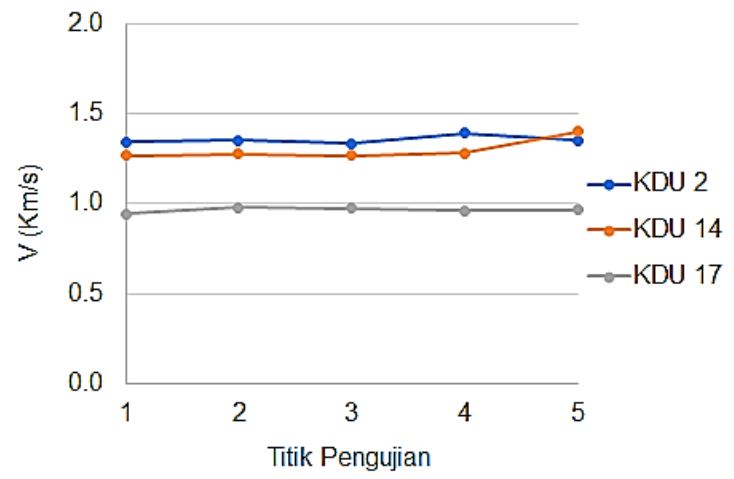

Gambar 6. Cepat Rambat Gelombang pada Kolom Cacat

Keterangan:

KDU $2=$ Kolom Direct Utuh 2 
KDU 14 = Kolom Direct Utuh 14

KDU $17=$ Kolom Direct Utuh 17

\section{Modulus Elastisitas Dinamik (MoEd)}

Nilai cepat rambat gelombang dapat digunakan sebagai dasar perhitungan modulus elastisitas dinamik. Berdasarkan hasil analisis MOEd pada kolom cacat dan kolom utuh tersaji pada Tabel 5 dan Tabel 6.

\begin{tabular}{|c|c|c|c|c|}
\hline $\begin{array}{l}\text { Kode } \\
\text { Kolom }\end{array}$ & $\begin{array}{c}\rho \\
\left(k g / m^{3}\right)\end{array}$ & $\underset{\left(\mathrm{m} / \mathrm{s}^{2}\right)}{\mathrm{g}}$ & $\begin{array}{c}V \\
(\mathrm{~km} / \mathrm{s})\end{array}$ & $\begin{array}{c}\text { MOEd } \\
\left(\mathrm{kg} / \mathrm{cm}^{2}\right)\end{array}$ \\
\hline KDC 11 & 0,6 & 9,81 & 0,74 & 3499,37 \\
\hline KDC 12 & 0,6 & 9,81 & 0,79 & 3982,55 \\
\hline KDC 27 & 0,6 & 9,81 & 0,59 & 2239,95 \\
\hline
\end{tabular}

Tabel 6. MOEd Kayu Jati pada Kolom Utuh

\begin{tabular}{ccccc}
\hline $\begin{array}{c}\text { Kode } \\
\text { Kolom }\end{array}$ & $\begin{array}{c}\boldsymbol{\rho} \\
\left(\mathbf{k g} / \mathbf{m}^{3}\right)\end{array}$ & $\begin{array}{c}\mathbf{g} \\
\left(\mathbf{m} / \mathbf{s}^{2}\right)\end{array}$ & $\begin{array}{c}\mathbf{V} \\
(\mathbf{k m} / \mathbf{s})\end{array}$ & $\begin{array}{c}\text { MOEd } \\
\left(\mathbf{k g} / \mathbf{c m}^{2}\right)\end{array}$ \\
\hline KDU 2 & 0,6 & 9,81 & 1,35 & 5891,64 \\
KDU 14 & 0,6 & 9,81 & 1,30 & 11579,42 \\
KDU 17 & 0,6 & 9,81 & 0,97 & 10652,04 \\
\hline
\end{tabular}

Hasil modulus keteguhan lentur dinamik jika dibandingkan dengan kode mutu pada SNI 7973-2013 untuk kolom cacat didapat nilai kekauan yang kecil dengan hasil K11 didapat E8, K12 didapat E8, dan K27 didapat E5. Dikarenakan adanya cacat terhadap kolom sangatlah berpengaruh pada nilai modulus keteguhan dinamik struktur kolom kayu yang diuji dengan UPV.

Sedangkan hasil modulus keteguhan lentur dinamik pada kolom utuh didapat nilai kekauan yang lebih besar dibanding kolom cacat dengan hasil K17 didapat E12, K2 didapat E14, dan K14 didapat E23. Dikarenakan kondisi kolom yang masih utuh dan tidak ditemukan cacat kayu pada kolom, sehingga nilai modulus keteguhan dinamik struktur kolom kayu yang diuji UPV mendapatkan nilai elastisitas dinamik yang besar.

Nilai keteguhan lentur dinamik pada kolom utuh yang lebih besar menunjukkan bahwa semakin kecil cacat kayu pada struktur semakin besar nilai modulus keteguhan lentur dinamik yang didapat. Kepadatan kayu yang utuh sangat mempengaruhi besarnya nilai kekakuan kayu yang diuji.

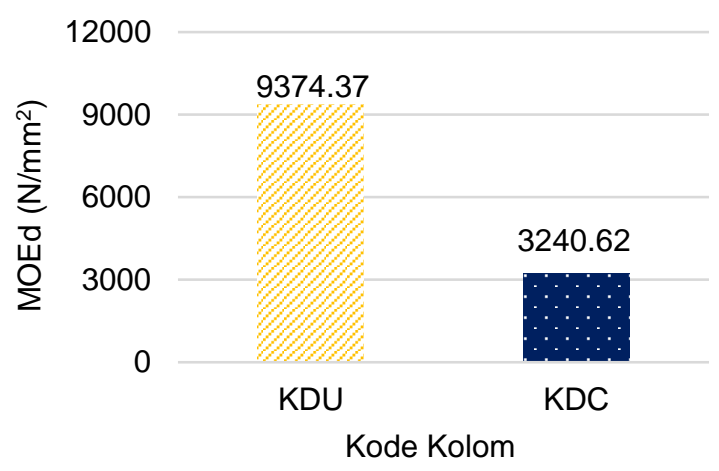

Gambar 7. Perbadingan Nilai MOEd

Berdasarkan Gambar 7 di atas, diperoleh modulus elastisitas dinamik rerata kode KDU, dan KDC berturut-turut sebesar $9374,37 \mathrm{~N} / \mathrm{mm}^{2}$, dan $3240,62 \mathrm{~N} / \mathrm{mm}^{2}$. Nilai modulus elastisitas dinamik pada kolom untuh yang lebih tinggi membuktikan bahwa kondisi dan keadaan cacat pada struktur bangunan kayu yang diuji dengan UPV test sangat berpengaruh pada nilai kekuatan dengan modulus elastisitas dinamik yang dihasilkan. Besarnya nilai degradasi yang terjadi pada Kolom Cacat terhadap Kolom Utuh saat diuji dengan pendekatan metode non-destructive test menggunakan metode direct yaitu didapatkan nilai degradasi $65,43 \%$. Hasil ini menunjukan bahwa nilai degradasi yang cukup besar difaktorkan oleh cacat kolom itu sendiri. Hal tersebut berarti bahwa Ultrasonic Pulse Velocity Method dapat digunakan untuk mengetahui besarnya penurunan (degradasi) material yang cacat dan kecepatan rambat gelombang serta modulus elastisitas dinamik yang dihasilkan. Namun demikian perlu dilakukan pengujian dengan metode lain untuk membandingkan efektifitas pengujian antara NDT dengan UPV dengan metode lain. 


\section{SIMPULAN}

Berdasarkan hasil analisis dan pembahasan dapat disimpulkan bahwa nilai kadar air dan berat jenis kayu Jati Bangunan Cagar Budaya berturut-turut adalah 15,03\% dan 0,62. Modulus elastisitas dinamik rerata kode KDU, dan KDC berturut-turut sebesar $9374,37 \mathrm{~N} / \mathrm{mm}^{2}$, dan $3240,62 \mathrm{~N} / \mathrm{mm}^{2}$. Jika dibandingkan dengan SNI 7973-2013 kolom utuh memiliki kode mutu kayu E20 sedangkan pada kolom cacat memiliki kode mutu kayu E14. Besarnya nilai degradasi kekuatan material pada struktur kolom cacat yang dibandingkan dengan kolom utuh melalui pengujian UPV yaitu sebesar $65,43 \%$.

\section{DAFTAR RUJUKAN}

American Society for Testing and Materials, (1992) reapproved (2003). Standard Test Methods for Direct Moisture Content Measurement of Wood and Wood-Base Materials, ASTM D 4442 92, West Conshohocken, United States.

American Society for Testing and Materials, (2014). Standard Test Methods for Density and Specific Gravity (Relative Density) of Wood and Wood-Based Materials, ASTM D 2395 - 14, West Conshohocken, United States.

American Society for Testing and Materials, (1994). Standard Methods for Testing Small Clear Specimens of Timber, ASTM D 143 - 94. West Conshohocken, Pennsylvania, United State of America.

American Society for Testing and Materials, (2003). Standard Test Method for Pulse Velocity Through Concrete, Designation: Vol. 04.02, ASTM C597 02. ASTM International

Departemen Kehutanan Badan Penelitian dan Pengambangan Kehututanan (2005). Atlas Kayu Indonesia Jilid I. Bogor

Haygreen, J.G., dan Bowyer, J.L. (1982). Hasil Hutan dan Hasil Kayu. Suatu Pengantar Terjemahan oleh Sutjipto A.
Hadikusumo (1989). Gadjah Mada University Press. Yogyakarta.

Nugroho, M. S., Awaludin, A., \& Supriyadi, B. (2017). Perencanaan Jembatan Pejalan Kaki Menggunakan Kayu Jati Hutan Rakyat Sebagai Material Konstruksi. INformasi dan Ekspose hasil Riset Teknik Slpil dan Arsitektur, 13(2), 141-153. https://doi.org/10.21831/inersia.v13i2. 17177

Peraturan Konstruksi Kayu Indonesia. (1961). PKKI NI - 5 (1961). Direktorat Jenderal Cipta Karya Departemen Pekerjaan Umum, Bandung

Undang-undang No. 11 tahun 2010 tentang Cagar Budaya 